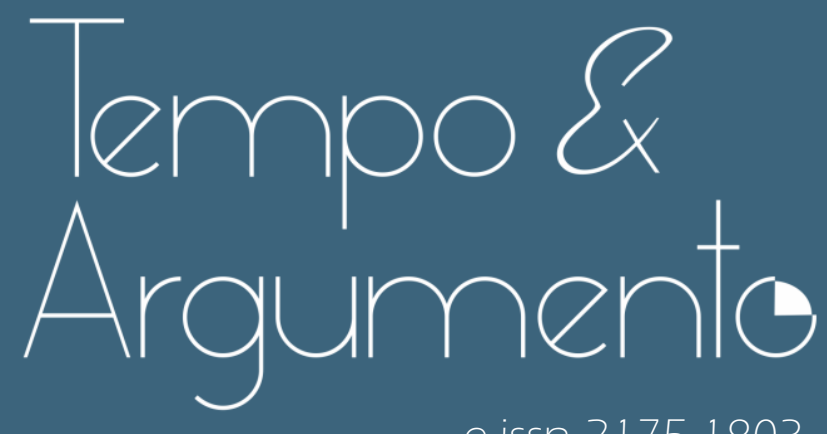

e-issn 2175-1803

\title{
"Welcome to Floripa" - The FIFA World Cup on the Magic Island: an apologia for sex tourism
}

- Marlene de Fáveri

Professor at the Department of History and the Graduate Program in History, area of concentration History of the Present Time, in the Center for Human Sciences and Education of the Santa Catarina State University (UDESC). Member of the Laboratory of Gender and Family Relations (LABGEF).

Florianópolis, SC - BRAZIL

lattes.cnpq.br/8610481850108967

mfaveri@terra.com.br

(iD) orcid.org/0000-0001-6245-1489

Translation of the article "'Welcome to Floripa" - A Copa do Mundo na Ilha da Magia: apologia ao turismo sexual" published in the Journal Tempo e Argumento, Florianópolis, v. 6, n. 13, p. 5-38, set./dez. 2014. http://dx.doi.org/10.5965/2175180307142015029

Translator: Evandro L. Freire Received on 09/29/2014 Approved on 12/16/2014 
"Welcome to Floripa" - The FIFA World Cup on the Magic Island: an apologia for sex tourism

\begin{abstract}
During the preparations for the Football World Cup in Brazil, Florianópolis received, in February 2014, a delegation of coaches of the national teams classified for the tournament, as well as journalists from all over the world. Sectors linked to tourism and the press gave special highlights to the event, hoping to invigorate international tourism and show the welcoming potential of the state of Santa Catarina. On the first day of the event, the newspaper Diário Catarinense distributed a special supplement, a kind of tourist guide to the city, entitled "Welcome to Floripa;" its cover featured an advertisement for a nightclub, the Bokarra Club, bearing images of women in erotic poses, an explicit apologia for sex tourism. I analyze the media impacts of these images, offered as objects of desire; letters exchanged between a public agency and this press medium; the resonance of this publication for male and female readers regarding sex tourism. I observe the uses of female images in the media, from the perspective of gender relations.
\end{abstract}

Keywords: Florianópolis; FIFA World Cup; Sex tourism; Media; Gender relations.

\title{
"Welcome to Floripa" - A Copa do Mundo na Ilha da Magia: apologia ao turismo sexual
}

\begin{abstract}
Resumo
Durante os preparativos para a realização da Copa do Mundo de Futebol no Brasil, Florianópolis recebeu, em fevereiro de 2014, a delegação de técnicos das seleções classificadas, bem como jornalistas de todo o mundo. Setores ligados ao turismo e à imprensa deram destaques especiais ao evento, na expectativa de revigorar o turismo internacional e mostrar o potencial acolhedor do estado de Santa Catarina. No primeiro dia do evento, o jornal Diário Catarinense distribuiu um suplemento especial, uma espécie de guia turístico da cidade, com o título "Welcome to Floripa"; estampava na capa a publicidade de uma casa noturna, o Bokarra Club, com imagens de mulheres em poses eróticas, em uma evidente apologia ao turismo sexual. Analiso os impactos midiáticos dessas imagens, oferecidas como objeto de desejo; cartas trocadas entre um órgão público e esse órgão de imprensa; as ressonâncias dessa publicação em leitores/as a respeito do turismo sexual. Observo os usos de imagens femininas na mídia, na perspectiva das relações de gênero.
\end{abstract}

Palavras-chave: Florianópolis; Copa do Mundo FIFA; Turismo sexual; Mídia; Relações de gênero.

\footnotetext{
This article is related to the project Sex Market in Florianópolis: territories, clients, and media in the Present Time, PIC/UDESC - 2010-2014. Scholarship students: Bruna Silveira Viana, Kamila Silva (PIC); Alessandra Ramos, Milene Chagas de Souza, and Larissa Vefago Dalmolin (PIVIC).
} 
This week Florianópolis will be one of the most watched cities on the planet. Representatives of the 32 national teams that compete for the FIFA World Cup will meet to discuss technical criteria for the competition. It is the chance that the city and the state have to consolidate as a world tourist destination (Diário Catarinense, Feb. 16, 2014).

The epigraph text, published in the newspaper Diário Catarinense on February 16, 2014, makes the promise of an auspicious destiny very clear for honorable visitors, representatives of the countries classified to compete in the greatest football world championship; they would provide the state of Santa Catarina and, more specifically, its capital city, with the opportunity to consolidate itself as a "world tourist destination." Resuming the discourse of half a century ago, the Florianópolis media echoed the wishes of the class of entrepreneurs linked to the tourism industry and designed a future for the capital of Santa Catarina: tourism as a natural destination, abandoning the project of turning it into an industrial city, according to enthusiastic plans in the making of the Master Plan. Reinaldo Lindolfo Lohn observes that great expectations of modernization were captured by the business sectors, the leading groups, and the middle classes. They lied on the "opening of real estate investment fronts," thus initiating "new opportunities for incorporations," which "moved the economy and, above all, reinforced the individual fortunes of those who were in a privileged position to predict and impose the city's urban configuration" (LOHN, 2007, p. 317).

The discourse pointed out by the contemporary Santa Catarina's media coincides with the time when Brazil was preparing to receive a number of tourists perhaps never seen before: hosting the 2014 FIFA World Cup. Football is the sport that attracts more spectators and fans in the world; its huge impact on the media breaks records of the most watched event on the planet in every World Cup (RIAL, 1995). Hosting the event, besides the country's international distinction or prominence, gives unparalleled visibility to the tourism and hotel industry and dynamizes it in proportions never reached in other events. Football is regarded as a big business since the beginning of last century, even losing to other sports modalities (GASPARETTO, 2013). On the other hand, it generates expectations and, in the case of this World Cup in Brazil, critiques against public expenditures (which led groups to the streets in protest), due to the "unorthodox set of 
positions" and State commitments, as well as the exacerbation of Brazilianness. Damo and Oliven (2013, p. 22) chose two aspects to be explored among "the innumerable possibilities of approaches that the hosting of mega-events in Brazil offer the nation's representations and the tensions around the uses of public money."

Florianópolis did not enter the route of the cities where the competitions would take place, but it guaranteed a place of prominence by receiving representatives of the technical commissions of the 32 national teams that would participate in the sports event². From February 18 to 20, 2014, all coaches of the national teams classified for the World Cup were in Florianópolis, which also attracted 120 press professionals from all over the world, and around 160 Brazilian journalists. To do this, 80 apartments were made available at the Costão do Santinho Resort, in the north of the Island, in its most noble area, near the beach. Among the pre-Cup events, this was the second in importance, behind only the World Cup's draw.

The press excitement about the arrival of visitors resonated in the sectors linked to tourism, especially in the Municipal and in the State Department, which determined as a strategy "generating information and spontaneous agendas that advance the event's sports nature and address the city as a tourist pole," so special kits with tourist information for Santa Catarina were made to deliver to journalists, "expectating" that "Florianópolis consolidated itself as an international destination." The newspaper Diário Catarinenses, which has a state-wide circulation and the most widely read, announced that "from this week on, Florianópolis will be on the agenda and in the mouth of the whole country, and if there is something welcome, more than FIFA and coaches, it is the city's exhibition." This press medium also wrote that "some qualities and defects that

\footnotetext{
Since 2009, Florianópolis sought to receive at least one of the actions classified for the FIFA World Cup. Unsuccessful in this application, its efforts aimed at receiving the draw for the groups or the Technical Congress. The latter was confirmed for Bahia. In March 2013, the investments were made for the Technical Congress in Florianópolis. In October 2013, the FIFA Secretary-General, Jérôme Valcke, confirmed that the 2014 FIFA World Cup's Technical congress would be held in Florianópolis.

${ }^{3}$ The newspaper Diário Catarinense began to circulate on May 5, 1986, as a project devised by the RBS Group's founder, Maurício Sirotzki Sobrinho. Today, out of the 293 municipalities in Santa Catarina, this newspaper circulates in 234; it dominates $91 \%$ of the print media advertising market in the Santa Catarina state capital, Florianópolis, and $61.3 \%$ in the rest of the state.
} 
affect everyday life will be put to the test, and this also means an opportunity for improvement and economic growth" (Diário Catarinense, Feb. 16, 2014).

To expose the city to the eyes of the world, it was necessary to enlarge the spaces of passage; investing in infrastructure and security; carefully planning the reception. If there were "critical points" that "needed attention not to scratch the island's portrait," efforts were made, in tune with the Public Power and FIFA, on security plans ${ }^{4}$ and infrastructure, so that nothing could stain the hospitable image. Thus, it was hoped to show visitors the best things it had and to "catapult tourism with that," in the words of Maria Cláudia Evangelista, Secretary of Tourism of Florianópolis. Rodrigo Herrero, sports editor, evaluated it as a "golden chance to strengthen the destination," or "a unique opportunity to strengthen Florianópolis' image internationally in the medium term as a tourist reference, since the congress and the city will be news in the leading newspapers around the world" (Diário Catarinense, Feb. 16, 2014).

According to secretary Maria Cláudia Evangelista, answering to the press about direct actions in the agendas to publicize the city:

[...] there is an already scheduled dinner, sightseeing, and nightly entertainment with visits to our nightclubs. Dinner will take place at the P12, on February 19. For journalists there will be some entertainment during dinner at the Simple On The Beach, also in Jurerê International"5 (Diário Catarinense, 16 fev. 2014, our emphasis).

The president of Santa Catarina Turismo S/A (SANTUR), Valdir Walendowsky, in line with the speech that projected a tourist destiny for the city and the state, bet: "the journalists that come to cover the event can elect some route, so they will return to their countries knowing a little more about us and they may come back on other occasions" (Diário Catarinense, Feb. 17, 2014).

\footnotetext{
Entitled "FIFA Congress: Extreme Vigilance," the protocol and the security scheme are announced, listing 13 federal and state institutions, as well as the mobilization of the Extraordinary Security Secretariat for Big Events, of the Ministry of Justice. The National Security Force, which was in SC during the second wave of attacks in February 2013, was mobilized in the city for the purpose of "controling civil disturbance and riots, escort, and close protection security to the FIFA Executive Committee Members” (Diário Catarinense, Feb. 17, 2014).

5 Pier 12 (P12) is a landmark of luxury tourism. At the 2012 carnival, Jurerê International was compared to Ibiza in terms of ostentation and opulence: images of women bathing in champagne at exorbitant costs appear in the media. Available at: http://duroeliso.blogspot.com.br/2012/01/jurere-internacional-tem-dinheiro-nem.html. Accessed on: Sep. 12, 2014
} 
Taking a part in the efforts of good reception, the coordinator of the Tourism Forum and president of the Association FloripAmanhã 6 , Elizenia Prado Becker, pointed out that "a support group for the Municipal Tourism Secretariat has been formed in order to welcome the tourists who arrive in Florianópolis," relying on a volunteer team for the reception work at the Hercílio Luz Airport during the three days of the event, distributing a kit with all information on the state and the city's attractions. She emphasized: "we have to think ahead, show the natural beauty, the quality of our hotels, the hospitality of the people, so that these virtues are spread and conveyed throughout the world" (Notícias do Dia, Feb. 17, 2014).

The practice of tourism is not just about traveling; is preceded by choosing the place to be known, according to the potential pleasures it can provide, obviously in line with the tourist's interest - beach, countryside, shopping, culture, sports, sex, etc. The media give decisive support to the choices, with ads delivered through newspapers, websites, folders, TV, official statements; they are persuasive, discursive systems that exert influence on the media, therefore, they are socially and culturally constructed. Out of all the material prepared for this purpose, however, I analyze an insert bearing the image of sexy women distributed on the opening day of the meeting where FIFA intended to persuade visitors by offering them an "island product."

The investments and efforts made in a courteous manner at this reception to journalists show actions designed to give visibility to the city and the state as welcoming, with the clear intent of promoting the internationalization of tourism, divulging its attractions to the world. This, of course, might attract more visitors in the future, aimed at middle-class and, above all, wealthy tourism. Such efforts are reasonable, given the event's significance, which would put the city and the state in the focus of international media for at least three days. Nevertheless, there is a however...

\footnotetext{
6 The Association FloripAmanhã, founded in 2005, aims at "contributing with strategies for sustainable development and construction of citizenship and social welfare" and "being the main non-governmental body devoted to think and propose solutions for the city." Available at: http://floripamanha.org/quem-somos/\#sthash.om34hoB1.dpuf. Accessed on: Sep. 12, 2014.
} 
In this article, I observe representations and investments, both public and private, aimed at the reception of coaches and journalists who came to Florianópolis on the occasion of the World Cup's referees meeting, through media discourses?. I focus specifically on the "special supplement" of a state-wide newspaper, aimed at tourism in general, but especially to honorable visitors; although there were female journalists, who were members of the various entourages, and many female FIFA employees, the vast majority were men. I analyze an ad for a nightclub in which a 'product' available in the city would be offered: women. I address the media impacts of this representation of female images offered as an object of sexual desire, and the resonance of the negative impact on many readers of both sexes, due to the association between this ad and sex tourism.

On February 18, 2014, the first day of the event, the newspaper Diário Catarinense circulated with an annex: a special supplement, entitled "Welcome to Floripa," which bears on its cover and back cover an ad for a local luxury striptease club, the Bokarra Club, a Class-A business establishment in the sex market of Florianópolis ${ }^{8}$. The 20-page publication is written in three languages (English, Portuguese, and Spanish) and it features a tourist itinerary for the state capital: bars, beaches, beach clubs, restaurants, concert halls, a guide to getting to know the Island.

The cover brings an ad for the Bokarra Club Striptease, announced as "The best strip club in Florianópolis," a sentence reproduced in Spanish and English; it also announces the opening hours, the location, the website, and payment accepted by credit cards. The highlight images consist in the bodies of five women: they are on their backs, have slender, sculptural bodies, all of them are white-skinned and long haired (two represented with black hair and the others with black blond hair), all of them wearing tiny bikinis, with drawings of flags of

\footnotetext{
I observe the discourse of various print and electronic media; I see them as a set of means of communication that integrate the mass media, which capture it from everyday themes that society recognizes; they produce, reproduce, inform, shape opinions and also deform them. According to Mauad (1996, p. 73), media images are "the result of a social work to produce meaning, based on culturally conventionalized codes."

8 The Bokarra Club was inaugurated on November 17, 1994, as a show house specializing in "striptease and performances by beautiful women, who make a beauty and sex appeal spectacle every night." In there, "people can find the highest concentration of beautiful women per square meter." Today, it has another house in Balneário Camboriú. Available at: http://www.bokarra.com.br/fpolis. Accessed on: Sep. 12, 2014.
} 
five countries participating in the World Cup. The women are in the foreground, with their feet on the sand and facing the sea; in the background, the image of the best known postcard of the Florianópolis Island, the Hercilio Luz Bridge, and an open sky appear. This cover suggests that either coming by land, sea, or air, visitors will find these women waiting for them.

Figure 1. Special supplement.

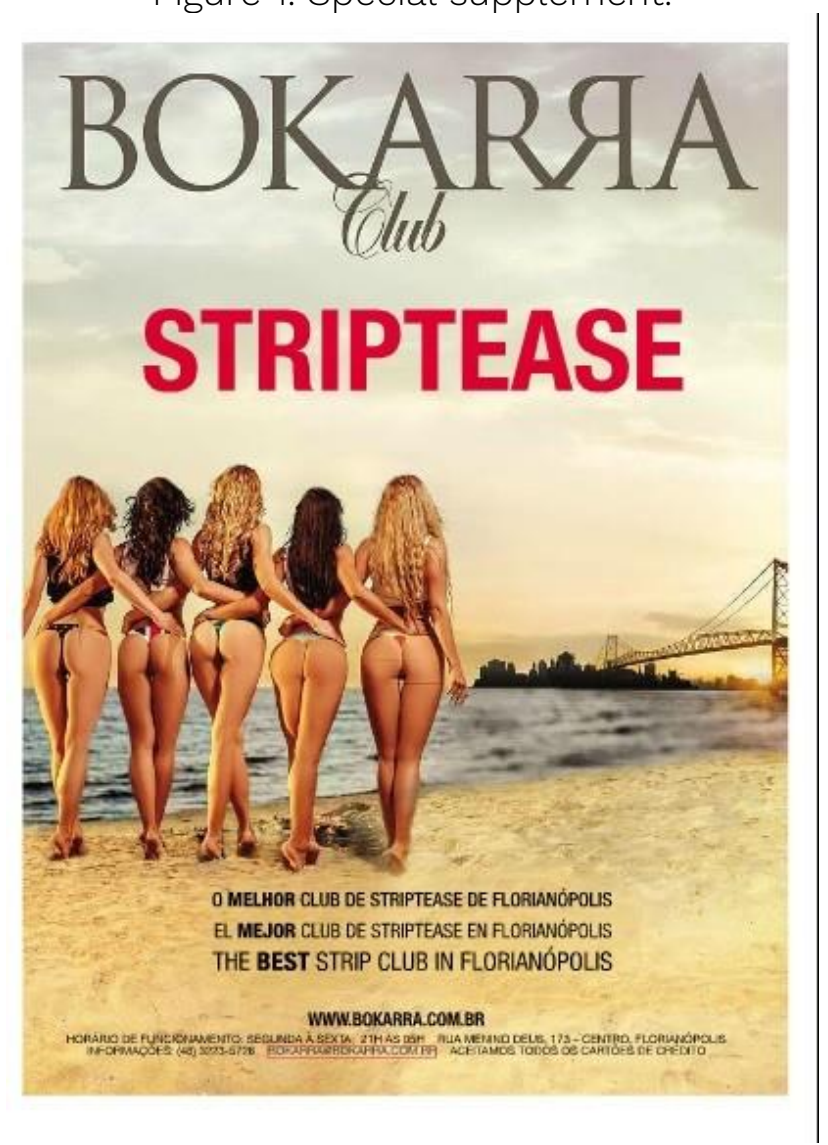

Source: Diário Catarinense, Feb. 18, 2014.

The image, by itself, is controversial. The representation is undeniably promising the pleasures available in the city. They are women in suggestive poses, arranged according to a marketing strategy, an image certainly chosen by the newspaper's editor, in agreement with the nightclub, which bought the advertising space. It is provocative and intends to draw attention, produce desires, and instigate the senses. Representation is, a priori, what is re-presented or makes "present an absence, but also exhibits its own presence as an image, and thus constitutes the person who looks at it as a looking subject" (CHARTIER, 2002, p. 165). The image carries meanings "commanded by the group's social properties or by the very resources of a power;" "Its efficacy depends on the 
perception and judgment of its addressees, adherence, or distance in the face of presentation and persuasion mechanisms put into action" (CHARTIER, 2002, p. 177-178). Thus, the relations that readers maintain with the world and social reality reflect a proper way of giving meaning to the world, according to which "all gestures, all behaviors, all objectively measurable phenomena are always the result of meanings that individuals assign to things, words, and actions" (CHARTIER, 2007, p. 33). Grasped like this, the representation of an ad image depends on the way how each subject/reader engages with it, as he/she evaluates, comments on, and ascribes meaning to what he/she sees/reads; I take into account that reading acts have plural and mobile meanings, in the meeting of collective or individual reading ways.

In Brazilian culture, codes that associate women with tourism have been recurrent. The image of Brazil and exuberant and cheerful Brazilian women already appeared in the letter by Pero Vaz de Caminha, or a paradisiacal land, both in its natural beauties and the Indian women's, who left their body shames naked, images that accompanied the writings about Brazil. In 1928, Paulo Prado associates the Brazilian people, since the colony, to lust and greed, placing "the issue of the central role played by sex discourse in the interpretation of national identity and Brazilian reality" (RAGO, 1997, p. 73), contributing to the stereotypes about women in the historical formation of Brazil, i.e. a colonized body. Later on, the mulattas were the symbol of the 'booty' woman in the Brazilian culture, export type, associated with the image of hospitable Brazil, "synthetic symbols of Brazilianness," which incorporate "the representation according to which the mulatto woman bears intrinsic qualities likely to be manipulated in white men's seduction rituals" (GIACOMINI, 1992, p. 244). The Brazilian Institute of Tourism (EMBRATUR) subsequently used images of half-naked black women as institutional tourism marketing in the Carnival advertising between 1970 and 1990, reinforcing the imagery of eroticized Brazilian women'. Adriana Piscitelli (2005), in an ethnographic study on relations between foreign tourists and Brazilian women, points out that racialized sexualization is gender-based, synthesized in the brown skin color embodied in women dating foreigners.

\footnotetext{
Osvaldo Sargentelli (1924-2002), TV presenter and night club business man, opened a show house in 1969 and worked on radio and TV programs where he publicized the mulattas; selfdefined as a 'mulattologist.'
} 
In the image conveyed, women are white, evidencing the ethnic origin. Florianópolis is the capital of a state known for its mostly white population, the result of a migratory process towards Southern Brazil in the mid-19th century, with a discursive and historiographic making that, for a long time, privileged groups of entrepreneurs and immigrants, leading other ethnic groups to become invisible. The capital is commonly associated with seaside geographic qualities, beaches of natural beauties, a discourse that began in the 1960s and it has been increasingly emphasized, both by real estate speculation and commercial and tourist ventures, private or public. Rafael Damaceno Dias (2009) observes that, since the second half of the $20^{\text {th }}$ century, Florianópolis, with the exploration of tourism, the intensification of the service industry, and the constitution of state and federal universities, acquired contours different from those of the colonial period. According to Márcia Fantin (2000), Florianópolis is known as the "Tourist Capital of the Mercosur;" its exuberant nature and quality of life have attracted a large number of people who come from other urban centers, provoking symbolic disputes around the city's projects.

Since the 1970s, real estate and tourism investments, allied to the Public Power, have focused on tourism, a more promising source of income; a desired destiny for the entrepreneurial class, appears in the local and state media of the time (LOHN, 2007). This process, along with the transformations and real estate speculation, emphasized a discourse of over-appreciation of the island's natural beauties, which has been claiming the state capital as a tourist pole. Investments were made in downtown redevelopment and cleaning; prostitutes were removed from the streets and cabarets, bars, and nightclubs (NONNENMACHER, 2010; FERRARI, 2008), and there was an accelerated migration in search of study opportunities and jobs ${ }^{10}$ that contributed to divulge a paradise named as "Magic Island"1. The press has been reproducing this discourse. One of the ways in which tourism was divulged consisted in associating natural beauties with beautiful

\footnotetext{
10 The Federal University of Santa Catarina (UFSC) was created in the 1960s; the School of Education, which would give rise to the Santa Catarina State University (UDESC), appeared in 1963; in the following decade, the arrival of the Centrais Elétricas S.A. (ELETROSUL) and the construction of the BR-101 took place, intensifying, as a consequence, the demand for housing, study, and jobs in the city.

${ }^{11}$ Perhaps the title of "Magic Island" to Florianópolis is an appropriation from the works by Franklin Cascaes (1908-1983), an artist from Florianópolis, whose drawings, sculptures, and writing disseminated the popular culture of the Island of Santa Catarina.
} 
native women, always white-skinned and smiling (FÁVERI, 2014). They reiterate, and thus reproduce, dominant values about the Brazilian women's model, shown and reactivated in the use of female bodies, with the clear purpose of provoking desire and providing it with the status of necessity, associating it with the city's geography and, in this case, its female inhabitants' geography. Therefore, the special supplement, notably focusing on the Island and its women, is not a novelty at all; this striptease club also announces on billboards, in roads of access to the city and the beaches, where female bodies appear in sexually appealing poses (Fig. 2).

Figure 2. Billboard.

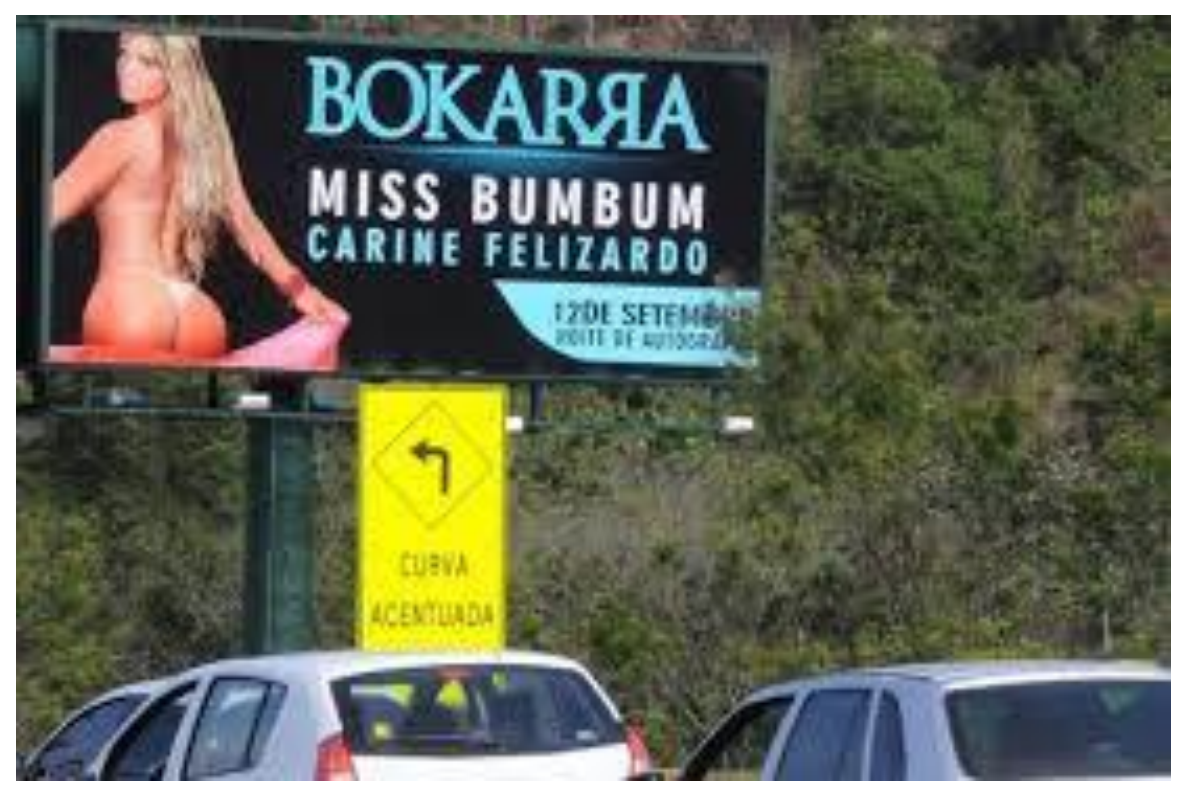

Source: Clube Bokarra. Rodovia SC 401. Florianópolis, 2013.

In the newspaper Diário Catarinense, representations of women's bodies as landmarks for tourism in Florianópolis city appeared as early as the 1970s:

When the sky is blue and the sun is burning they do not need anything more than a bikini to further embellish nature. Each one has her secret, her recipe to charm. On the weekends of this scorching summer, all girls in the world populate the island and the mainland beaches. [...] Eroticism is present on the beaches and each woman's curves hide a mystery full of sorcery, the fascination that radiates from them is enough to justify the summer season, if it did not have other pleasures and other privileges to offer (O Estado, Jan. 25, 1970). 
The text above, published by a local columnist, Sérgio da Costa Ramos, announces the atmosphere of "eroticism that is present on the beaches and on every woman's curves," offering the possibility to add "other pleasures and other privileges" that the summer season in such a Magic Island offers to tourists. Since then, images and representations in this sense have been published; they contribute to divulge a kind of 'Florianopolitan,' 'islander,' 'native' woman, 'manezinha'12, an exuberant-looking woman, different from the multiplicity of women from various social classes, skin colors, and generations that we see day after day on the streets, marking ethnic characteristics and gender representations.

Analyzing the images of women that appear on the pages of the newspaper Diário Catarinense between 2000 and 2014, focusing on tourism (FÁVERI, 2014), I perceive a certain regularity in the form and content through which they are represented. The images observed naturalize behaviors, stereotypes, and concepts that do not fit the reality of women from Florianópolis. The most popular and elitist festivals and nightclubs on the beaches were also observed Praia Mole, Canasvieiras, Jurerê International, Conceição Lagoon, Costão do Santinho -, which are those attracting tourists in the summer season ${ }^{13}$. Festivals like the Cacau's Feijoada, promoted by the columnist on the Carnival Saturday (in 2014, it reached 22 editions), brings together people who circulate in high society, politicians, tourists, and feature musicians, sportsmen/sportswomen, TV artists, and guests. As reported on the blog, "what we saw in Cacau's Feijoada

\footnotetext{
12 The term 'manezinho/manezinha,' used in the press, identifies native inhabitants of both sexes on the Island of Santa Catarina, and carries its own meanings. The debate about this identification began in 1987 - 'manés' and 'manezinhos' - in the search of characteristics peculiar to the inhabitants of Florianópolis, with symbolic and cultural artifices; the term manezinho/manezinha started having a positive connotation, thus identifying native inhabitants of the Island.

${ }^{13}$ Especially on the pages of a local columnist, Cacau Meneses, who has maintained them since 1996, where he makes various commentaries on the city, the festivals, the local culture, tourism; in them, women appear with highlights for beauty and exposed bodies in inviting poses. Cacau comes from a tradition in islander journalism, as a Manoel de Menezes' son, a journalist known and recognized in the Santa Catarina state press, who left his son with the legacy of his name and his history, granting him an authoritative voice. In addition to the column, Cacau maintains a blog, a program section on the RBS TV's Lunch News, local primetime news, as well as a program he has maintained on Rádio Atlântida, "Macrophonics," from 5:00 p.m. to 6:00 p.m., since October 2010, i.e. he is rooted in the local media, where he plays a role of influence.
} 
was a show of beautiful people on all sides. Humble people, politicians, powerful men and women... yes, powerful women, beautiful, hot, and flaming [...]"14, evidencing the festival's tone and reproducing discourses that have been repeated for decades in the local media, generally focusing on the female body attributes, associated with the beauties of the island's lush nature.

On the back cover of the special supplement I am referring to, there are a beach and sea scene, a typical island canoe, trees, or a set of meanings that represent the island and associate it with a piece of paradise. The supplement repeats the welcoming invitation, also in three languages, and announces: "a guide to know all the ways of the Island of Santa Catarina;" in the page footer, there is the ad: "Bokarra Club, the best night Floripa":

Figure 3. Back cover of the special supplement.

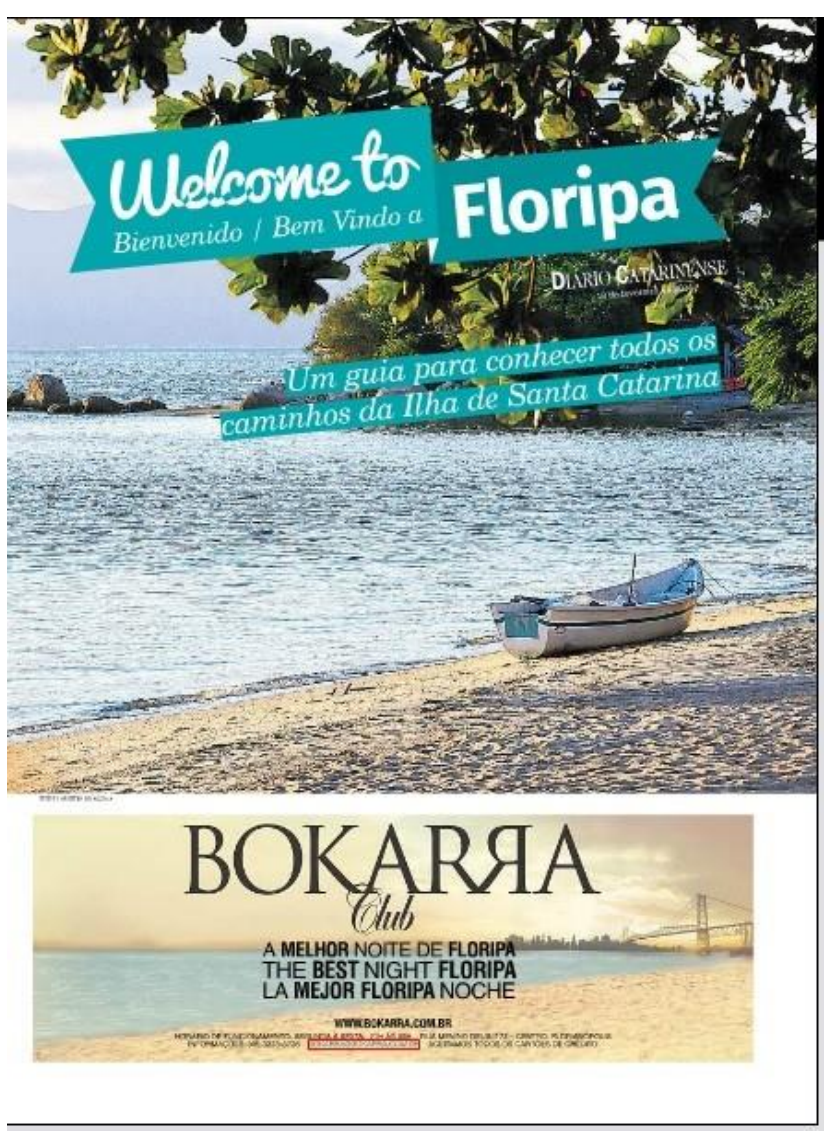

Source: Diário Catarinense, Feb. 18, 2014.

\footnotetext{
Available at: http://wp.clicrbs.com.br/cacaumenezes/2013/02/03/feijoada-do-cacau-3 and http://wp.clicrbs.com.br/cacaumenezes/2013/02/10/feijoada-dos-pes-sujos-e-das-pernasde-fora/?topo=67,2,18,38,77. Accessed on: Sep. 12, 2014.
} 
The ad for the striptease club, in the special supplement, provoked protests on the part of the city's inhabitants. This piece of marketing entered the social media and the local (and national) press, associating itself with the apologia for sex tourism. In the insert that I am analyzing, the ad image captures the ideals that circulate and reproduces them, producing meanings. The analyses of journalistic sources contribute to reflections about gender relations, cultural constructions imbricated into power relations, since the press representations of these female 'bodies' are connected to what the society accepts and 'consumes' at a given time. In a study on media consumption, Ruth Sabat (2003, p. 152) evaluates that "working with gender and sexuality representations in advertising entails a critical potential" and "it is possible to identify how body types, ways of living, behaviors, and values presented in the images are socially constructed."

As an insert, the special supplement was distributed to subscribers and possible readers. According to a female worker's report, present at the Costão do Santinho Resort, the distribution of an insert having the photos "was prohibited by the event's administration"15, preventing its distribution. There was no newsstand on-site (due to competition with FIFA sponsors). The official said that she learned of the publication "through the social media and the Santa Catarina's press," and that "people who had access to this material were very indignant, and even ashamed, especially women." Following, "the distribution of information material against sex exploitation to the event's participants was intensified," at the same time, contact was made with "the press office in order to lead them to ask the RBS." People's annoyance, especially those associated with the State Tourism, Culture and Sports Secretariat, with a vast majority of women, realized that this publication undermined all of the Secretariat's recent work against child sex exploitation. I notice that the state has not officially positioned itself on the issue. The movement to repudiate the newspaper came from people who felt outraged by the content and image of the ad under analysis, many of them linked to the tourism industry.

15 Informal reports by P., employee of the event, who does not want to be identified. On September 17, 2014. Florianópolis. To Marlene de Fáveri. 
I notice there was sensitivity on the part of the event's organizers and the administration of the hotel that hosted the congressmen, who did not allow the distribution of this insert at the event site. The respondent's and other female workers' annoyance during the event, as well as some men's annoyance, was added with the annoyance of thousands of posts on the social media. On the very day of the supplement's publication, and in the following days, on the social media and other media outlets, the posts came from critiques full of angriness. Lawyer Manoel Menezes posted the cover and back cover images on his Facebook page, entitled "WELCOME TO FLORIPA, THE CITY OF PROSTITUTION," where he reports what happened, saying that he was "angry" about the Diário Catarinense:

Yes, that's right, the ad for a prostitution club features the insert cover, page three (below the index of material) and the back cover of it. For a country that fights against sex tourism and against the 'image' of a whoring and sexually promiscuous country, this is somewhat contradictory, not to mention exactly what I think of it. Deep down, the person who 'fights' sex tourism is the same who consumes it. And sex tourism is the biggest gateway to child prostitution.

The fact that the prostitution club has paid a high sum to be there leaves no room for doubt, but to what extent must profit speak louder? The largest newspaper in the state, the largest communication group in Southern Brazil, which also advocates the fight against sex tourism, allows itself to advertise this kind of contents in an insert totally focused on foreigners because it received a considerable amount of money? Moreover, we know that sex tourism is a matter of shame.

Suddenly, everything is worth and the 'ethics' and the commitment to the population and the reasons why are left behind?

Congratulations RBS! What a beautiful first impression. You do not represent us (although you have 'Catarinense' in the name of one of your newspapers), much less Floripa; what you did was a disservice to the entire population of Floripa and Santa Catarina, and you should apologize, indeed!

In this commercial relationship between Prostitution Club $\times$ Diário Catarinense (RBS), I unfortunately cannot say which side the prostitutes are in... in fact, prostitutes are on both sides of this relationship. What a shame!

I'll start avoiding the RBS, that's all!16

\footnotetext{
16 Available at: https://www.facebook.com/photo.php?fbid=10151875762931809\&set =pcb.10151875773961809\&type=1. Accessed on: Sep. 12, 2014 .
} 
Shared on various social media, this post generated comments with complaints about this kind of advertising on the island, many in anger against the newspaper itself, like this: "now the campaign should read: CANCEL YOUR SUBSCRIPTION TO THE DIÁRIO CATARINENSE!!! The DC cannot drag the image of our people into the mud"17; or "[...] I think the RBS group should care a little more about this kind of apologia, because it receives money from the government to run campaigns against child prostitution... this is at least incoherent?" A part of the netizens highlights the city's problems, hidden behind paradise advertisements, and the cost of that event to the public coffers. The website of the Association FloripAmanhã has published a note by journalist Carlos Damião, one of the editors of the column "Ponto Final" in the newspaper Notícias do Dia, from Florianópolis, on February 20, entitled "Second-rate citizens," with reverberations in society, such as these:

On the social media, in the chat groups, in the informality of the cafe or the bar, many Florianopolitans manifest themselves by wishing a FIFA standard for public security, for public health, public education and infrastructure. I received emails, comments, and messages from people astonished at the events surrounding the Fifa Technical Congress, ranging from the distribution of an immoral ad for sex tourism to the powerful security scheme, relying on the participation of the Armed Forces, the Brazilian National Force, the Federal Police, the Federal Highway Police, the Military Police, and the Civil Police. Everything to protect foreign delegations called for the World Cup preparatory meeting. "Considering the treatment given by the Brazilian Federal Government and the Santa Catarina State Government, we can at least be sure that: we, the inhabitants, are second-rate citizens. We are not FIFA standard citizens," Fernando Carlos Pereira, a resident of the neighborhood Ingleses, told me. He even sees that the event "should have a special treatment, indeed, due to its greatness and international repercussion. But we, who pay taxes, deserve the same (or better) attention by the State" (our emphasis) $)^{18}$.

This text is followed by others written by netizens who put the investments in financial resources for receiving the congress participants into

\footnotetext{
17 Available at: https://www.facebook.com/photo.php?fbid=10151875762931809\&set= a.426430211808.192064.699361808\&type $=1 \&$ comment_id=10096116\&offset=0\&total_comments =19. Accessed on: Sep. 12, 2014.

${ }^{18}$ Available at: http://floripamanha.org/2014/02/cidadaos-de-segunda-categoria. Accessed on: Sep. 12, 2014.
} 
question, while hospitals, schools, security, infrastructure are lacking, just as the reader Roberto Grisard Clausen did, who registered his impression:

Embarrassed and terrified should be (the rulers) in face of the exorbitant amounts of money spent on white elephants. There is no money to improve schools - classes have been postponed in Florianópolis due to lack of infrastructure - but there is money enough to receive the football elite at a frankly outrageous price.

Other readers associate child prostitution ${ }^{19}$ with the way how the press deals with this fact: by ignoring it and by making an apologia for sex tourism. The netizen Maria Goulart, talking about advertising material to stimulate sex tourism, noticed: "as a woman and a native Florianopolitan, I felt offended, insulted, and outraged." Many women wrote demonstrating feelings of shame, angriness, annoyance, disqualification, and disappointment. Heloisa Buarque de Almeida (2013, p. 232) recalls that, when reading a newspaper, people "already have opinions, viewpoints, and even a local culture in which they live;" they "do not passively assimilate everything they see, read, or listen to in the media. They negotiate meanings, partly or completely disagree."

The Portal da Itha (online), on the day after the publication, reproduces the cover image of the supplement, highlighting: "the newspaper Diário Catarinense has published a tourist insert addressed to foreigners who participate in the event, sponsored by the Bokarra Club," and: "the ad for an erotic show club in Florianópolis published on a special insert in the largest newspaper in Santa Catarina was very badly received" ${ }^{20}$. The (online) newspaper Brazil Post ${ }^{21}$, on the same February 18, highlights the controversial image. Entitled "Catarinenses revolt against the ad for a strip club in the state's largest newspaper," it comments on the fact by emphasizing the post written by the netizen Manoel Menezes mentioned above (also publishing the address of his page on Facebook).

In this newspaper - Brasil Post - numerous reports appear denouncing sex tourism due to the World Cup, either by publicizing actions in the Brazilian states to curb sex exploitation during the event, or by denouncing the marketing

\footnotetext{
19 The repercussions and laws on the issue of child prostitution are not analyzed in this article.

20 Available at: http://www.portaldailha.com.br/noticias/lernoticia.php?id=21240. Accessed on: Sep. 12, 2014.

${ }^{21}$ Available at: http://www.brasilpost.com.br/2014/02/18/turismo-sexual-santa-catarina_n_ 4810219.html._Accessed on: Sep. 10, 2014
} 
campaigns whose ads incited sex tourism. The newspaper also highlights the speech by Embratur president Flávio Dino, who reinforced the repression of sex tourism: "sex exploitation is an unacceptable crime and it cannot be confused in any way with a tourism modality;" "our effort is focused on the promotion of Brazil by its natural and cultural attributes. Such an initiative ignores and disrespects the communication line adopted by the government"22.

The repercussion of the publication of this ad for the Bokarra club was the object of much criticism of people living in the city and it gave rise to speeches with different tones; with rare exceptions, focusing on the relation of images to sex tourism appeals. The issue's repercussion on the social media and the pressure from society and people linked to the Tourism Secretariat, more precisely those who worked directly with actions to prevent sex tourism in the city, encouraged official measures. In the afternoon of February 18, Elizenia Prado Becker, coordinator of the Florianópolis Tourism Forum (FORTUR) ${ }^{23}$, addressed a letter ${ }^{24}$ to Eduardo Sirotsky Melzer, president of the RBS Group and the latter, expressing to the "Dear Sirs" his "astonishment" about the publication of the insert "Welcome to Floripa," put the contents into question, as fully transcribed here:

The FORTUR - Florianópolis Tourism Forum, hereby expresses its surprise about the publication of DC "Welcome to Floripa - A guide to know all the ways of the Island of Santa Catarina," on February 18, 2014.

Contrary to the efforts made by the various government agencies and media outlets at the national level to curb and discourage the sex tourism practice, it is a matter of surprise that a special tourism insert has content of an erotic nature, sponsored by a show club. This action jeopardizes all the city's efforts to favorably impress the 600 Brazilian and foreign visitors attending the FIFA Congress, in preparation for the World Cup.

Florianópolis has a potential for growth based on the commitment of society as a whole to achieve quality of life for all its citizens. The commitment of media outlets, in our understanding, must be so that Florianópolis manages to combine its social and economic

\footnotetext{
${ }^{22}$ Available at: http://www.brasilpost.com.br/2014/02/25/dilma-adidas-camiseta_n_ 4854297.html...Accessed on: Sep. 10, 2014.

23 The FORTUR - Florianópolis Tourism Forum -, coordinated by FloripAmanhã, was created on March 5, 2014. It brings together representative entities of the tourist trade, the business sector, and civil society of the Santa Catarina's capital city; it aims to articulate and create synergy between entities linked to tourism, Public Power, and society.

24 Available at: http://floripamanha.org/2014/02/carta-do-fortur-sobre-anuncio-em-cadernowelcome-floripa-e-resposta-do-dc. Accessed on: Sep. 16, 2014.
} 
growth to resuming and appreciating its history, arts, heritage, and people.

To do this, the mass media need to experience the city, its challenges and problems, participating in the effort to build it with a view to turn it into an international reference in quality of life and tourism.

Taking into account the significance of the Diário Catarinense, as the main newspaper in SC and as an opinion maker, there is a need for greater care in dealing with these issues, which may undermine the serious and committed work done by the tourism entities in our city and state to elevate Florianópolis to the status of, admittedly, one of the best tourist destinations in Brazil and in the world.

By stating that the publication goes "against" the efforts of the Public Power and the national media to "curb and discourage the sex tourism practice," that its content of an erotic nature "jeopardizes all the city's efforts to favorably impress the 600 Brazilian and foreign visitors," the speech points out actions that have been carried out long before the World Cup at the local and national levels, especially with regard to grooming of minors for sexual exploitation during the event $^{25}$. In 2012, the Santa Catarina State Tourism, Culture and Sports Secretariat, in partnership with the Ministry of Tourism, organized the $1^{\text {st }}$ Seminar on Sustainable Tourism and Childhood/SC, in order to foster actions to prevent children and adolescents' sex tourism in the state, already worried about the upcoming World Cup.

In April 2012, a Brazilian Parliamentary Inquiry Commission (CPI) was set up in the Brazilian Chamber of Deputies. The commission, which investigated children and adolescents' sex exploitation for two years, issued a report and showed the seriousness of this problem in the country, highlighting the points of vulnerability. The report also called for changes in legislation to improve the protection of children and adolescents victims of this kind of crime. On May 27 , 2014, this commission signed a pact with the Brazilian Football Confederation (CBF) to fight children and adolescents' exploitation, abuse, and trafficking in sports clubs.

\footnotetext{
${ }^{25}$ In April 2013, the newspaper O Globo published a report entitled "Enticers already act in the World Cup cities," indicating that on the roads connecting the 12 host cities for the World Cup there were child enticers, and that 1,969 vulnerable points had been found, as investigated by the Federal Prosecutors' Office. Available at: http://oglobo.globo.com/brasil/aliciadores-jaatuam-em-cidades-da-copa-do-mundo-12310760. Accessed on: May 25, 2014.
} 
In March 2013, on the occasion of International Women's Day, Eleonora Menicucci, from the Women's Policy Secretariat of the Presidency, expressed in an interview her concern about advertisements alluding to the World Cup, which induced sex tourism: "I do not admit it, the president does not admit it, the government as a whole, it's zero tolerance with sex tourism," she emphasized, referring to an Adidas's campaign that produced T-shirts allusive to Brazil and women, like the one written in English with the sentence "Lookin' to score," next to a very provocative woman ${ }^{26}$. Likewise, she publishes the president's speech: "Dilma condemns Adidas for a shirt with sexual references to Brazil in the 2014 World Cup," referring to the sports material company and official World Cup sponsor, which distributed T-shirts with explicit apology to sex tourism, resulting in an official request from the government for the withdrawal of this material from circulation.

The fight against sex tourism is a State policy in Brazil (and not a government policy), which has been promoting campaigns aimed at curbing this practice. The preparation for the events held in Brazil - 2013 Confederations Cup, 2014 World Cup, 2016 Olympic Games - include policies to control children and adolescents' sexual exploitation. This has reached all social classes and is also linked to cultural aspects, such as unequal relationships between men and women ${ }^{27}$. In these events, particularly, the circulation of women (many of them teenagers) intensifies among the various states of the country. The owner of a show club in Balneário Camboriú, Santa Catarina, for instance, received as an "order" sending 20 "southern girls" to Rio de Janeiro; there, they would "meet a particular team, which guarantees a huge pay deal"28.

It is a matter of great annoyance that women are historically accountable for pursuing this job. Their subjection to such a sex market network, promoted by offering pleasures to men - clients lying on a splendid cradle of their own -, illustrates the articulation of power relations. Joan Scott (1990, p. 16) shows this overt link between power and gender, whose inequality dimension is based on

\footnotetext{
${ }^{6}$ Newspaper Brasil de Fato (online). Available at: http://www.brasildefato.com.br/node/27647. Accessed on: Sep. 17, 2014.

27 Violência sexual: um fenômeno complexo. Available at: http://www.unicef.org/ brazil/pt/Cap_03.pdf. Accessed on: Sep. 17, 2014.

${ }^{28}$ Testimony by $\bar{N}$. D., the show club owner. Florianópolis, mar. 25 , 2014. To Marlene de Fáveri.
} 
hierarchical structures. According to the author, "gender is a first way of providing power relations with meaning," in a set of references that "structure the conception and actual and symbolic organization of social life as a whole." That is, both the women who appear in the supplement image and those who were "sent" to meet a team evidence generalized concepts about being a man and being a woman: a gender built for enjoying pleasures and exerting the power to obtain an accessible "object;" and another gender represented by bodies available to players; in this case, in order to satisfy male desires in dribbling and kicking during the virility game.

I notice that the letter's content expressed in the text by the FORTUR on the ad emphasizes the "media commitment" to significant social issues; it asks for care in "dealing with these issues," which undermine the "serious and committed work done by the tourism entities in our city and state to elevate Florianópolis to the status of, admittedly, one of the best tourist destinations in Brazil and in the world." This letter was immediately disseminated on the various media outlets and shared ad nauseam. Therefore, it deserved an official response.

The following day, Eduardo Smith, vice-president of Newspapers, Radios, and Digital Media of the South Brazil TV Network Group (RBS) ${ }^{29}$, responds to the letter, as shown in full text below:

Dear Zena,

I write on behalf of Nelson, Eduardo, and the entire Diário Catarinense team.

We agree it was a mistake to publish the ads featured on the insert "Welcome to Floripa," because they are misleading, convey an image that is not in line with what we advocate for tourism in Florianópolis.

The Diário Catarinense has strong editorial principles, it appreaciates the relationship with the community, it is directly committed to coping with the city problems and fostering growth and tourism in Florianópolis. This commitment makes us feel even sorrier when we make a mistake like that noticed in this insert. I am sure that our entire team will learn, by thinking through this episode and the constructive criticism provided by people like you, to choose the right path to follow and improve the service we deliver to the community.

29 Available at: http://floripamanha.org/2014/02/carta-do-fortur-sobre-anuncio-em-cadernowelcome-floripa-e-resposta-do-dc. Accessed on: Sep. 16, 2014. 
We lean on our long-running partnership, as well as on our relation to the entities you represent, in order to fulfil this purpose.

Thank you for drawing our attention to the problem and talking as clearly as you always do.

A strong hug to you.

This response takes an informal tone not consistent with the document received from an official body. Addressing the FORTUR coordinator, Elizenia Prado Becker, as "Dear Zena," an approach taken to deal with private affairs, undermines her authority, as well as the Tourism Forum's. He also disregards an issue to be seriously dealt with. The sender, in the answer's content, does not have a proper name or a link to the body she represents. The answer is short, and it talks about a "misunderstanding," "a mistake" made, and he insists on the "strong editorial principles" of the Diário Catarinense in "coping with the city problems and fostering growth and tourism in Florianópolis," without delving into the information content or its repercussion. I assume that the recipient qualifies this as a minor fact for the newspaper and its staff, which may be addressed informally, as a misunderstanding. But the question remains: if the sender was a man, would he deserve the same treatment?

When it happens that someone, on her/his own behalf or on behalf of a group, claims to be offended, freedom of the press is usually invoked; however, the Brazilian Press Law ${ }^{30}$ allows the publication and circulation, in the national territory, of books, newspapers, and other sequential publications, but it does not allow "offending public morals and good customs" (Article 17). The law also regulates the rights of reply, to be published "in the same newspaper or sequential publication, in the same place, by using the same typographic characters that have been used in the writing that gave rise to the complaint, and in an usual issue and publication date" (Article 30). That is, Eduardo Smith's response, i.e. on behalf of the vice-presidency of the RBS, as we can see, is short and informal, disregarding the rule of law.

\footnotetext{
30 Brazilian Press Law: Law No. 5,250, enacted on February 9, 1967. Updated until January 2000. Documentation and Information Center. Coordination of Publications. Brasília - 2000. Available at: http://www.estadao.com.br/infograficos/2009/03/arq45fc47c34f81c.pdf. Accessed on: Sep. 14, 2014.
} 
There was, of course, a new flood of posts and comments on the social media, now highlighting the RBS's "apology" or "misunderstanding." As it is not feasible to mention all comments, I highlight one of them, written by the netizen Rodrigo André Pompermayer:

IN THE FACE OF THIS EPISODE???????? They were irresponsible, inconsequential, they favored prostitution, linked the state to this???? Although this was not the intent, the message conveyed it, indeed, the foreigners view about Brazil is not enough? That is, here is the land of easy women and girls who trade sex for money, this puts us in evidence again regarding sex tourism. We really DID NOT NEED IT, I'm ashamed of being a Catarinense citizen; if it is up to me, DC will not have a penny out of my pocket, because if that's what the money of subscribers and readers pay for the printed newspaper, it is not worth a penny at all; and if it is up to me, this second-rate newspaper, which was once respectful, honored, and trustworthy, can stop the presses definitively. I'm totally disappointed ${ }^{31}$.

This comment summarizes the feeling of the vast majority of readers, who overtly reject the piece of marketing featured on the "special supplement," which exposes the city and its women in a negative way (only this post received 800 comments). Likewise, other comments reject the newspaper, linking this press medium to Rede Globo de Televisão, whose editorial line has been quite partial in relation to private interests, conniving with the political culture in a country where TV networks play a key role in terms of providing the political activity with visibility, and present in disputes over power.

The association of the special supplement with sex tourism appears in the comments, and not without reason. Concern about sex tourism practices in mega-events is pointed out by the World Tourism Organization (UNWTO), a specialized agency of the United Nations. It sees that the term 'sex tourism' makes this practice equal to other tourism forms regarded as legitimate, such as rural tourism, business tourism, cultural tourism, etc. It suggests that the most suitable terminology for the issue of 'sex tourism' is 'sexual exploitation through tourism.' The UNWTO, as for prevention, defines sex tourism as 'trips organized within the tourism industry, or out of it, but using its structures and its networks, with the main purpose of making it easier for tourists to pay for having sex with

\footnotetext{
${ }^{31}$ Available at: https://pt-br.facebook.com/diariocatarinense/posts/685953731445892. Accessed
} on: Aug. 20, 2014. 
people who live in the place of destination." The World Code of Ethics in Tourism "overtly prohibits, through its principles, sex exploitation of human beings, since tourist purposes must always promote and observe Human Rights" (CUNHA, 2013).

Although the newspaper does not mention prostitution, the Bokrra Club is a luxury prostitution club, different from the prostitution services available on the streets and by day in Florianópolis (FÁVERI, 2010). In Brazilian law, prostitution is not criminalized; the business establishments operate as 'massage parlors,' bars, VIP clubs, night clubs, and they avoid inspection by resorting to this modus operandi. Both the media that publishes the insert and the night club that pays for advertising are not criminalized; so, the newspaper does not break the law, the market rationale makes it clear. Nevertheless, as mentioned above, this goes against the efforts to curb the Brazilian women's stereotyped image, in this case, women from Santa Catarina, and associates them with a 'product' available, whose erotic connotation re-updates the recurring representations about them. Advertising reflects conventional standards regarding female and male models and it is aware of the consumer and market rationale, regardless of discourses and actions going against the body's nakedness and its relation to feasible uses. In this case, in order to meet a sex demand by visitors, this product follows the triumphant rationale of male power.

Football is related to masculinity; in turn, femininity, in several studies ${ }^{32}$, emerges to violate the spectacle rationale and the game ethics (BITENCOURT, 2007), as well as fan performances and male sociabilities concerning football (GASTALDO, 2005). Other studies show the circulation of players in migratory processes (RIAL, 2008); or the insertion of women in sports (FRANZINI, 2005; C. S. ALMEIDA, 2013), now widely practiced and widespread, as well as their presence in the stadiums, not only to guarantee heteronormativity in a space populated by men, but, according to Rial (2014), present in various sectors that involve games in the present time.

\footnotetext{
${ }^{32}$ In the 2007 edition, in the event "Making Gender: body, violence and power," held in Florianópolis, at the Federal University of Santa Catarina (UFSC), a Thematic Symposium had as its theme "Football: femininities and masculinities at stake," opening up for research on the theme. Available at: http://www.fazendogenero.ufsc.br/8/st71.html. Accessed on: Sep. 12, 2014.
} 
Football is a sport traditionally associated with masculinity, virility, and strength. The stadiums are "a specific cultural context, a place that institutionalizes practices, teaches, produces and represents masculinities" (BANDEIRA, 2010). In this way, relations with football (as well as other sports associated with masculinity) produce discourses and images that associate women to men's domination. According to Welzer-Lang (2001, p. 461), the predatory sexuality model is key to the male gender constitution, and it is formed through the idea that women are an object for consumption; the author thinks that "men dominate women collectively and individually. This domination is exercised in the private or public sphere and it assigns to men material, cultural, and symbolic privileges."

Advertising for a nightclub, aimed exclusively at the male audience, evidences such a domination and assigns to men a set of references built for leisure/pleasure, in which they can practice their attributes of masculinity and virility. According to Nolasco (1995, p. 25), "the male gender is a category set up as a repertoire of identifications and behaviors that guide men." Moving away from what belongs culturally to the female universe - not crying, being a provider, being competitive, showing to be capable, showing strength, virility - is regarded as an attribute of masculinity. Visitors (tourists) would be socially recognized as potential providers; besides social position and distinction (being in a select group), they would have the financial resources to pay for women regarded as high level ones, or for those who work at the Bokarra Club. Masculinity, as a social standard that regulates men's behavior, is "at the same time, the position in gender relations, in the practices by which men and women commit themselves to this gender position and the effects of these practices on the bodily experience, on personality, and on culture" (CONNEL, 1997, p. 6). Out of all the sports considered, or more widely accepted, for the male gender, football is what mostly evidences the 'virility dance.'

This same society, or a considerable part of it, believes that male desire/drive needs a safe, hygienic, cheap, easily accessible, fast, risk-free, anonymous, uncompromising place, as if it were natural to exercise masculinity by obtaining women on a commercial basis. The 'client' subject does not exist in 
advertising, and this is reasonable; he is a consumer of the 'product' offered, and virility signs correspond to what is expected of him: a provider for women and a decision-maker in the trade sector he leads. Janice Raymond (2004) shows this invisibility of client men; they are those who 'buy women's bodies' and 'abuse women in prostitution,' arguing that both U.S. agencies, governments, nongovernmental organizations (NGOs), among others, disregard sex exploitation on the basis of male demand, reproducing the sexist order that exploits women.

The discourses and representations published by the media outlets are related to what society knows and produces in terms of meanings; thus, "pieces of advertising have a symbolic structure that is designed to convince us about the significance and necessity that a particular product takes in our lives," in the words of Ruth Sabat (2003, p. 13). Advertising for a streptease club and its target audience presupposes this necessity, disregarding symbolic violence, undermining women's rights by embodying them in the set of 'all women' in the Magic Island. The gender marks are also constructed by media representations that reiterate and reproduce femininities and masculinities according to the patterns of a certain dominant ideology. An example of this appeared in a TV program in June 2014, when presenter Luciano Huck 'summoned' viewers to find 'girlfriends' for gringos who would visit Brazil on the occasion of the World Cup ${ }^{33}$.

Representations of women from Santa Catarina, such as how these gender marks have been associated with tourism, appear on a bag produced by Santa Catarina Turismo (SANTUR), in 2011, in order to be distributed in promotional events. On the bag, one reads "Discover Santa Catarina," and the image features a woman's body, trimmed, covered with a beach yoke; she is white-skinned and her legs are exposed:

\footnotetext{
${ }^{33}$ In June 2014, the Caldeirão do Huck TV program's website, which belongs to presenter Luciano Huck, published: "Carioca? Single woman? Crazy to find a charming prince among the 'gringos' who are invading Rio de Janeiro during the Cup? Your time has come... send photos and tell us why you want a gringo tailor-made for you through this email: namoradaparagringo@globomeial.com." There was a flood of criticism, linking the ad with sex tourism. Available at: http://negrobelchior.cartacapital.com.br/2014/06/25/luciano-huckenvolvido-em-polemica-de-turismo-sexual. Accessed on: Sep. 12, 2014.
} 
Figura 4. Advertising.

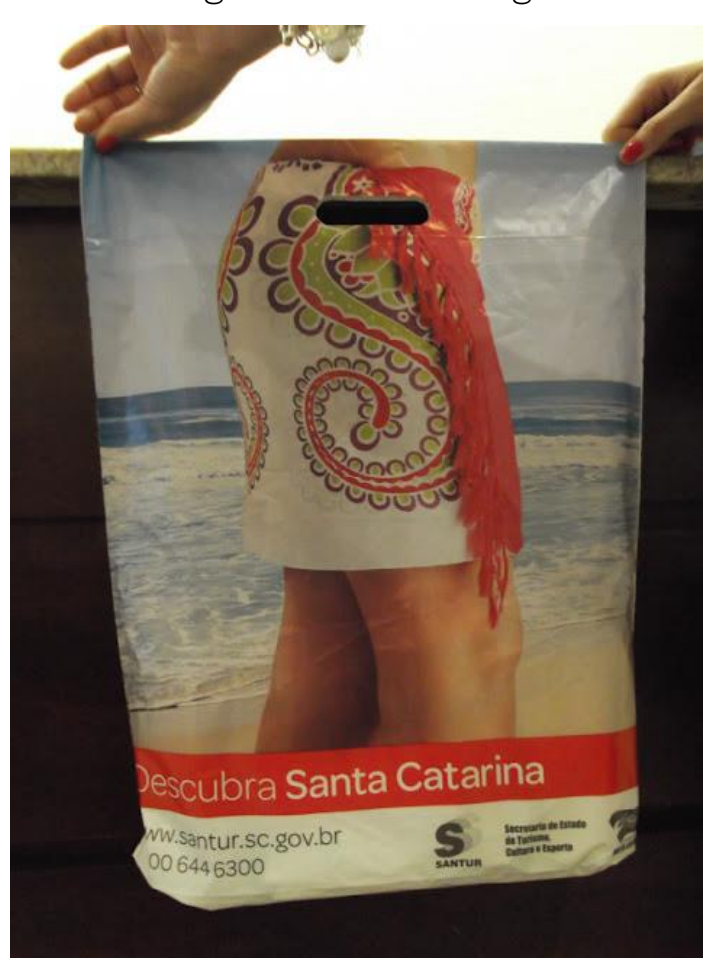

Fonte: http://botecodabete.blogspot.com.br/2011/12/santur-e-divulgacao-sexualizada-do.html. Acesso em: 12 set. 2014.

The sexualized connotation is appealing, provocative, explicit; i.e. it is an invitation to 'discover' Santa Catarina through the women's body. This material was criticized, mocked, and provoked embarrassment and shame, according to Bete's account: "I see everywhere campaigns against sex tourism; Brazil is struggling to stop being the destination of this kind of people. It seems that our state has decided to take advantage of this 'niche market'..." The feeling: "I was disgusted. Santa Catarina has much more to offer than a "piece of meat'!" 34 . Addressed like an object, without face, without personality, a woman emerges as if the state of Santa Catarina was the natural extension of what is covered. These bags were immediately withdrawn from circulation after overt protests on the social media, as well as protests by women who work in the very Tourism Secretariat, as they felt demeaned. I ask: who thinks of this kind of advertising for the state, within the sphere of public power, does not realize the mismatch with efforts to curb representations in this way?

34 Available at: http://botecodabete.blogspot.com.br/2011/12/santur-e-divulgacao-sexualizadado.html. Accessed on: Sep. 12, 2014 
This image, and that featured on the special supplement, enhances sexuality and eroticism; they link tourists motivation to an imagery of paradise, notably with heteronormative division, related to a kind of sex tourism that has been gaining space: men looking for sex. Contemporary tourism has a nature mediated by seduction, by detail. Promotional materials, either public or private, have invariably used sexy female images. Krippendorf (2003, p. 40-41) tells us that the imagery of paradise is strongly driven by tourism entrepreneurs, who act according to economic interests without worrying about the motivation that can propel tourists to choose a certain destination. The speeches observed in the media when preparing to receive the delegation of World Cup coaches and the journalists reiterate the investment in the visibility of a welcoming city that offers world-class tourist activities, aimed at the elites, thus putting it on the international scene. The image produces a 'postcard' that goes against actions to curb abuses and favors a type of trade that undermines human rights.

The supplement analyzed herein does not, of course, advertise sex tourism or prostitution - although this is implicit -, but it reinforces women's eroticization in Santa Catarina; beautiful women from the Magic Island take a leading role in these ads. It is a way of talking about tourism by offering sexualized attractions, as well as featuring class, ethnic, and generation distinctions. The images have gained the world through cyberspace, and certainly penetrated the imagery of users in the international sex tourism circuits. Adriana Piscitelli (2005) observes the breadth of the transnational sex market, the codes, the websites existing in the sex tourism geography; the author informs that this market tends to grow due to ease of communication through the social media.

The Western culture has constructed and it still constructs differential gender prescriptions for men and women; women were assigned to behaviors aimed at drawing men's attention, the so-called providers. In turn, men were assigned to masculinity codes that allow them to look for sex wherever they are, seduced by sexually appealing advertising. I do not condemn the female (or male) body exposure practices, but the uses that naturalize behaviors and make all women vulnerable to a traveler or tourist's eyes and senses. 
All sources used herein evidence the practice of some media outlets that convey images such as that featured on the special supplement, making the traces of a macho culture explicit. I recall that images are chosen by people who work in newspapers (or other media outlets), still attached to a culture in which women are seen as 'products,' offered as a compensation for the choice of this or that place to travel to. On the other hand, our sources show there was a huge repercussion, including repudiation claims, so that the inserts were withdrawn from circulation. This tells us there are changes and that many people are more attentive to this kind of symbolic gender violence. The impacts of representation by using the image offered as an object of desire in the ad I have observed may be evaluated throught resonance on the social media and the printed media, as we have analyzed. The complaints, in the heat of the moment, the indignant posts, the Tourism Secretary's attitude of preventing the distribution and withdrawing the insert from circulation show there was mobilization. This reveals people attentive to sexism and its reverberations. However, assessing the impact on consumers of the 'product' offered is, of course, unfeasible.

The letters, both the one expressing repudiation of the insert contents and asking for explanation from the press medium and that responds to it, have provoked heated demonstrations. This does not exempt the newspaper from liability for negligent behavior; so, this did not pass unscathed. Did the city's destiny change after the World Cup? If international tourism is going to grow as the speeches cried out loudly, we do not know, yet. But it is possible that, for the future of the city, or its destiny, there is going to be greater care in the dissemination of this kind of image or greater reluctance to do so. We hope so! 


\section{References}

ALMEIDA, Caroline Soares de. Boas de bola: um estudo sobre o ser jogadora de futebol no Esporte Clube Radar durante a década de 1980. 151 f. Dissertação (Mestrado em Antropologia Social) - Universidade Federal de Santa Catarina, Florianópolis, 2013.

ALMEIDA, Heloisa Buarque de. Mídia, sociedade e cultura. In: ALMEIDA, Heloisa Buarque de; SZWAKO, José (Orgs.). Local, global. São Paulo: Berlendis e Vertecchia, 2013. p. 202-237.

BANDEIRA, Gustavo Andrada. Um currículo de masculinidades nos estádios de futebol. Revista Brasileira de Educação, Rio de Janeiro, v. 15, n. 44, maio/ago. 2010.

BITENCOURT, Fernando Gonçalves. Telespetáculo e futebol: descompassos no sistema discursivo e ético. Disponível em:

<http://webcache.googleusercontent.com/search?q=cache:pZpzj6WEFRAJ:www .labomidia.ufsc.br/index.php/acesso-aberto/publicacoes/publicacoes2007/doc_download/279-tele-espetaculo-e-futebol+\&cd=1\&hl=ptBR\&ct $=c l n k \& g l=b r>$. Acesso em: 1 set. 2014.

CHARTIER, Roger. À beira da falésia: a história entre certezas e inquietude. Porto Alegre: Ed. UFRGS, 2002.

CHARTIER, Roger. A história ou a leitura do tempo. Belo Horizonte: Autêntica, 2007.

CONNEL, Robert. La organización social de la masculinidad. In: VALDÉS, T.; OLAVARRÍA, J. Masculinidades. Santiago: Ediciones de las Mujeres, 1997. p. 1-25.

CUNHA, Juliana Frei. Tráfico humano, exploração e "turismo sexual" em tempos de megaeventos esportivos: falácia ou realidade de difícil comprovação? In: SEMINÁRIO INTERNACIONAL TRÁFICO DE PESSOAS PARA EXPLORAÇÃO SEXUAL OU TRABALHO SEXUAL, 3., 2013, São Paulo. Anais... São Paulo: Universidade Estadual Paulista, 2013.

DAMO, Arlei Sander; OLIVEN, Ruben George. O Brasil no horizonte dos megaeventos esportivos de 2014 e 2016: sua cara, seus sócios e seus negócios. Horizontes Antropológicos, Porto Alegre, v. 19, n. 40, p. 1-45, jul./dez. 2013.

DIAS, Rafael Damaceno. Que invasão é essa? Leituras sobre conflitos socioculturais em Florianópolis (1970-2000). 137 f. Dissertação (Mestrado em História) - Universidade Federal do Paraná, Curitiba, 2009. 
FANTIN, Márcia. Cidade dividida: dilemas e disputas simbólicas em Florianópolis. Florianópolis: Cidade Futura, 2000.

FÁVERI, Marlene de. As 'piriguetes de Floripa': práticas contemporâneas de propagandas de sexo pago. In: FÁVERI, Marlene de; PEDRO, Joana Maria; SILVA, Janine Gomes da (Orgs.). Prostituição em áreas urbanas: histórias do tempo presente. Florianópolis: Ed. Udesc, 2010. p. 17-43.

FÁVERI, Marlene de. "As garotas são bonitas e sorriem prá você": imagens de mulheres e mídias na Ilha da Magia. In: MOREIRA, Rosemeri; CAMARGO, Hertz Wendel de; KLANOVICZ, Luciana Rosar Fornazari (Orgs.). O gênero e os meios: imprensa, televisão e cinema. Londrina, PR: Syntagma, 2014. p. 55-66.

FÁVERI, Marlene de; SILVA, Kamylla. Mídias, mulheres e mercado do sexo: ambiguidades e consumo. Gavagai: Revista Interdisciplinar de Humanidades, Erechim, v. 1. n. 1, p. 70-79, mar./abr. 2014.

FERRARI, Maryana Cunha. Vila Palmira: prostituição e memória na Grande Florianópolis nas décadas de 1960 a 1980. 126 f. Dissertação (Mestrado em História) - Universidade Federal de Santa Catarina, Florianópolis, 2008.

FRANZINI, Fábio. Futebol é "coisa para macho"? Pequeno esboço para uma história das mulheres no país do futebol. Revista Brasileira de História, São Paulo, v. 25, n. 50, jul./dez. 2005.

GASPARETTO, Thadeu Miranda. O Futebol como negócio: uma comparação financeira com outros segmentos. Revista Brasileira Ciência do Esporte, Florianópolis, v. 35, n. 4, p. 825-845, out./dez. 2013.

GASTALDO, Édison. "O complô da torcida": futebol e performance masculina em bares. Horizontes Antropológicos, Porto Alegre, v. 11, n. 24, jul./dez. 2005.

GIACOMINI, Sônia Maria. Aprendendo a ser mulata: um estudo sobre a identidade da mulata profissional. In: COSTA, Albertina de Oliveira;e BRUSCHINI, Cristina (Orgs.). Entre a virtude e o pecado. Rio de Janeiro: Rosa dos Tempos, 1992. p. 213-245.

KRIPPENDORF, Jost. Sociologia do turismo: para uma nova compreensão do lazer e das viagens. São Paulo: Aleph, 2003.

LOHN, Reinaldo Lindolfo. Limites da utopia: cidade e modernização no Brasil desenvolvimentista (Florianópolis, década de 1950). Revista Brasileira de História, São Paulo, v. 27, n. 53, p. 297-322, 2007.

MAUAD, Ana Maria. Através da imagem: fotografia e história interface. Tempo, Rio de Janeiro, v. 1, n. 2, p. 73-98, 1996. 
NOLASCO, Sócrates. A desconstrução do masculino. Rio de Janeiro: Rocco, 1995.

NONNENMACHER, Marilange. Conselheiro Mafra: a alma de uma rua chamada "pecado". In: FÁVERI, Marlene de; SILVA, Janine Gomes da; PEDRO, Joana Maria (Orgs.). Prostituição em áreas urbanas: histórias do tempo presente.

Florianópolis: Ed. Udesc, 2010. p. 95-114.

PISCITELLI, Adriana. Sexo tropical: comentários sobre gênero, raça e outras categorias de diferenciação social em alguns textos da mídia brasileira.

Cadernos PAGU, Campinas, v. 6/7, p. 9-35, 1996.

PISCITELLI, Adriana. Gênero e racialização no contexto de relações transnacionais: comentários a partir de uma leitura das relações presentes no turismo sexual em Fortaleza (Ceará, Brasil). In: SIMPOSIO INTERNACIONAL: O DESAFIO DA DIFERENÇA, 1., 2000, Salvador. Anais... Salvador: Universidade Federal da Bahia, 2000.

PISCITELLI, Adriana. Viagens de sexo on-line: a internet na geografia do turismo sexual. Cadernos Pagu, Campinas, v. 25, p. 281-326, jul./dez. 2005.

RAGO, Margareth. Sexualidade e identidades na historiografia brasileira. Revista Resgate, Campinas, n. 7, p. 59-74, dez. 1997.

RAYMOND, Janice. Prostitution on demand: legalizing the buyers as sexual consumers. Violence Against Women, Thousand Oaks, v. 10, n. 10, p. 1156-1186, 2004.

RIAL, Carmen. Futebol e mídia: a retórica televisiva e suas implicações na identidade nacional, de gênero e religiosa. Antropolítica: Revista Contemporânea de Antropologia e Ciência Política, Niterói, n. 1, p. 61-88, 1995.

RIAL, Carmen. Rodar: a circulação dos jogadores de futebol brasileiros no exterior. Horizontes Antropológicos, Porto Alegre, v. 14, n. 30, jul./dez. 2008.

RIAL, Carmen. A participação das mulheres na mídia brasileira na Copa. 2014. Disponível em: <http://cuadernosdelmundial.clacso.org/opinion6.php>. Acesso em: 20 ago. 2014.

SABAT, Ruth. Gênero e sexualidade para consumo. In: LOURO, Guacira Lopes; NECKEL, Jane Felipe; GOELNER, Silvana Vilodre (Orgs.). Corpo, gênero e sexualidade: um debate contemporâneo na educação. Petrópolis, RJ: Vozes, 2003. p. 149-159.

SCOTT, Joan. Gênero: uma categoria útil de análise histórica. Educação e Realidade, Porto Alegre, v. 15, n. 2, p. 5-22, jul./dez. 1990. 
WELZER-LANG, Daniel. A construção do masculino: dominação das mulheres e homofobia. Revista Estudos Feministas, Florianópolis, v. 9, n. 2, p. 460-482, 2001. 